\title{
PRODUKTIVITAS PENULISAN ARTIKEL JURNAL ILMIAH DOSEN FAKULTAS ILMU SOSIAL DAN ILMU POLITIK UNIVERSITAS PADJADJARAN
}

\author{
Teguh Sandjaya dan Rd. Daniar Muliawan \\ Fakultas Ilmu Sosial dan Ilmu Politik, Universitas Padjadjaran \\ Email: teguh.sandjaya@unpad.ac.id
}

\begin{abstract}
Abstrak
Tujuan dikeluarkannya Permenristekdikti Nomor 20 Tahun 2017 adalah untuk: 1) mendorong dosen yang sudah berada pada jenjang jabatan akademik Lektor Kepala dan Profesor untuk melaksanakan tugasnya sebagai pendidik profesional dan ilmuwan dengan melaksanakan tridarma perguruan tinggi secara sungguh-sungguh, 2) mendorong Lektor Kepala dan Profesor untuk secara aktif dan produktif melakukan publikasi ilmiah di jurnal nasional terakreditasi, jurnal internasional, dan jurnal internasional bereputasi, dan 3) meningkatkan jumlah publikasi dosen dan ilmuwan Indonesia pada tingkat internasional sehingga mampu bersaing dengan publikasi bangsa-bangsa lain sejalan dengan Nawacita serta untuk memperoleh rekognisi internasional terhadap publikasi ilmiah ilmuwan Indonesia.

Namun seiring berjalannya waktu, perkembangan minat menulis para dosen khususnya di Universitas Padjadjaran, khususnya di lingkungan Fakultas Ilmu Sosial dan Ilmu Politik dalam 3 tahun terakhir ini, baik dosen yang memiliki jabatan akademik sebagai Asisten Ahli, Lektor, Lektor Kepala, maupun Guru Besar, tercatat adanya peningkatan prestasi dalam publikasi ilmiah internasional.

Metode yang digunakan penelitian kualitatif deskriptif dengan instrumen penelitian berupa kuisioner, wawancara, observasi, dan dokumentasi. Berdasarkan hasil penelitian menunjukan bahwa faktor internal yang mempengaruhi Produktivitas Penulisan Artikel Jurnal Ilmiah di Kalangan Dosen FISIP Unpad, pada pernyataan: Profesi yang saya miliki, dituntut untuk selalu membuat/menulis karya tulis ilmiah dengan skor 191. Sedangkan pda faktor eksternal yang mempengaruhi Produktivitas Penulisan Artikel Jurnal Ilmiah di Kalangan Dosen FISIP Unpad, pada pernyataan: Fakultas dan Universitas, memberikan insentif jika karya tulis ilmiah dapat publish di jurnal setiap 6 (enam) bulan 1 kali (semester) dengan skor 167 .
\end{abstract}

Kata Kunci: Produktivitas; Artikel Jurnal Ilmiah; Jabatan Akademik

\section{PENDAHULUAN}

Peraturan Menteri Pendidikan dan Kebudayaan (Permendikbud) Nomor 49 tahun 2014 tentang Standar Nasional Pendidikan Tinggi (SN-DIKTI) merupakan bagian dari implementasi atas Undang-Undang Nomor 12 Tahun 2012 tentang Pendidikan Tinggi. Standar ini menyangkut Standar Nasional Pendidikan, Standar Nasional Penelitian, dan Standar Nasional Pengabdian kepada Masyarakat. Dalam Pasal 46 (2) UU ini dinyatakan, bahwa hasil penelitian wajib disebarluaskan dengan cara diseminarkan, dipublikasikan, dan/atau dipatenkan oleh Perguruan Tinggi. Dipublikasikan dalam arti hasil penelitian dimuat dalam terbitan berkala ilmiah yang terakreditasi nasional atau bereputasi internasional. Untuk memenuhi tuntutan ini, maka diperlukan terbitan berkala ilmiah yang berkualitas dalam berbagai bidang dalam jumlah yang cukup, agar peneliti mempunyai wadah yang cukup banyak untuk mempublikasikan artikel bermutu yang jumlahnya dari tahun ke tahun semakin meningkat.
Data yang ditampilkan SCImago Journal and Country Rank (SJR) terhadap jumlah artikel di kisaran tahun 1996-2016 menunjukkan posisi Indonesia yang berada di ranking 55 dunia.

Tabel 1. SJR Ranking of Indonesia

\begin{tabular}{|c|c|c|c||}
\hline H index & Documents & Citations & $\begin{array}{c}\text { Citations per } \\
\text { document }\end{array}$ \\
\hline \hline 175 & 54146 & 380569 & 7.03 \\
\hline
\end{tabular}

Sumber:http://www.scimagojr.com/ countrysearch.php?country=id

Untuk memperbaiki peringkat dilihat pada tabel 1, beberapa upaya telah dilakukan Dikti untuk meningkatkan aksesibilitas, visibilitas, standar pengelolaan, serta kualitas terbitan berkala secara nasional. Terbitan berkala Indonesia yang dikelola menjadi $e$ journal dan terindeks Directory of Open Access Journal (DOAJ) meningkat secara signifikan, dimulai dari 29 terbitan berkala 
pada tahun 2011 menjadi 109 terbitan berkala pada pertengahan tahun 2014, serta semakin meningkat di tahun 2017 yaitu menjadi sejumlah 1194. Dalam pengindeksan internasional, di tahun 2017 terdapat 43 terbitan berkala Indonesia yang masuk dalam indeks Scopus. Jumlah ini diharapkan terus meningkat untuk memperbaiki posisi Indonesia dalam publikasi karya ilmiah di level internasional.

Teknologi informasi dan komunikasi membawa perubahan besar terhadap sistem pengelolaan terbitan berkala sampai pada penentuan indeks sitasi dan pengukuran dampak ilmiah suatu artikel. Akreditasi terbitan berkala yang selama ini dilaksanakan secara manual harus turut dikonversi menjadi secara elektronik. Perubahan ini akan mempercepat pelaksanaan akreditasi, sekaligus memperbaiki mutu proses akreditasi. Dengan cara tersebut diharapkan lebih banyak terbitan berkala nasional dengan mutu yang baik, yang dapat didorong menjadi terbitan berkala yang bertaraf internasional.

Perkembangan sistem teknologi dan informasi saat ini, khususnya lingkungan institusi pendidikan berdampak pula pada pengelolaan dan penerbitan berkala ilmiah yang semula tercetak dengan proses yang terbilang cukup lama, kini menjadi lebih cepat dengan proses elektronik. Aktivitas pengiriman, penyuntingan, penelaahan, dan penerbitan naskah karya ilmiah dilaksanakan dalam suatu sistem aplikasi yang dinamakan terbitan berkala ilmiah elektronik (e-journal). Dengan sistem tersebut, maka proses pengindeksan dan dampak ilmiah atau sitasi suatu tulisan pun akan diketahui dengan cepat, sehingga manfaat karya tulis ilmiah (KTI) dapat diketahui khayalak umum segera.

Perubahan paradigma dari terbitan berkala ilmiah cetak menjadi elektronik harus diikuti perkembangannya, baik oleh penulis maupun kalangan penerbit di Indonesia, sehingga hasil karya yang dihasilkan, dapat segera diketahui dan dikenal masyarakat baik nasional maupun internasional. Perubahan Perubahan paradigma tersebut sebaiknya diikuti oleh peraturan-peraturan yang mendukung. Adanya penghargaan dan sanksi dari penentu kebijakan terkait terbitan berkala ilmiah berkualitas melalui proses akreditasi terbitan berkala ilmiah, juga proses penilaian angka kredit bagi peneliti atau dosen untuk artikel-artikel ilmiah yang dipublikasikan melalui jurnal ilmiah, akan mendukung ke arah positif perubahan paradigma tersebut.

Berdasarkan Undang-undang Nomor 14 tahun 2015 tentang Guru dan Dosen, pada pasal 60 dinyatakan bahwa dalam melaksanakan tugas keprofesionalan, salah satu kewajiban dosen antara lain melaksanakan pendidikan, penelitian, dan pengabdian kepada masyarakat.

Selanjutnya, berdasarkan Undangundang Nomor 12 tahun 2012 tentang Pendidikan Tinggi pada pasal 12 ayat (2) dan (3) dinyatakan bahwa dosen sebagai ilmuwan memiliki tugas mengembangkan ilmu pengetahuan dan/atau teknologi melalui penalaran dan penelitian ilmiah serta menyebarluaskannya. Selain itu juga, Dosen wajib melakukan publikasi ilmiah sebagai salah satu sumber belajar.

Peraturan Menteri Riset, Teknologi dan Pendidikan Tinggi Nomor 20 tahun 2017 tentang Tunjangan Profesi Dosen dan Tunjangan Kehormatan Profesor, didalamnya mencantumkan peraturan yang mewajibkan dosen yaitu bagi yang memiliki jabatan akademik Lektor Kepala dan Profesor untuk melakukan publikasi ilmiah. Kewajiban dalam melakukan publikasi ilmiah ini adalah kewajiban dosen sebagai seorang ilmuwan yang wajib mengembangkan ilmu pengetahuan dan teknologi, serta wajib untuk menyebarluaskannya hasil karya ilmiahnya kepada masyarakat.

Peraturan Menteri Riset, Teknologi dan Pendidikan Tinggi Nomor 20 tahun 2017 lebih memberikan penekanan kewajiban publikasi ilmiah ini bagi dosen yang memiliki jabatan akademik tinggi, yakni Lektor Kepala dan Profesor. Hal ini disebabkan karena penanganan pengelolaan karir jabatan akademik Lektor Kepala dan Profesor berada di bawah tanggung jawab langsung Kementerian Riset, Teknologi dan Pendidikan Tinggi di tingkat pusat.

Sementara itu, keharusan publikasi ilmiah untuk dosen yang memiliki jabatan akademik Asisten Ahli dan Lektor telah diatur dalam Peraturan Menteri Penertiban Aparatur Negara dan Reformasi Birokrasi Nomor 17 tahun 2013 tentang Jabatan Fungsional Dosen dan Angka Kreditnya.

Dalam Permen PAN \& RB tersebut dinyatakan bahwa dosen yang ingin memperoleh jabatan akademik Asisten Ahli, atau kenaikan jabatan dari Asisten Ahli ke 
Lektor, atau dari Lektor Kepala, maka dosen tersebut harus memiliki publikasi ilmiah. Untuk dosen di Perguruan Tinggi Negeri (PTN) yang memiliki jabatan akademik Asisten Ahli dan Lektor, penanganan pengelolaan karir jabatan akademiknya diserahkan kewenangannya kepada Perguruan Tinggi Negeri (PTN) yang bersangkutan. Sedangkan bagi dosen di Perguruan Tinggi Swasta (PTS), maka pengelolaannya ditangani oleh Koordinator Perguruan Tinggi Swasta (Kopertis)/Lembaga Layanan Pendidikan Tinggi.

Permenristekdikti Nomor 20 tahun 2017 yang mewajibkan publikasi untuk Lektor Kepala dan Profesor adalah dalam rangka mendorong peningkatan kuantitas dan kualitas publikasi ilmiah pada tingkat nasional dan internasional. Meningkatnya jumlah publikasi pada jurnal internasional dan jurnal internasional bereputasi akan mendorong Indonesia mampu bersaing dengan bangsabangsa lain. Pada tahun 2017, tercatat bahwa jumlah publikasi internasional Indonesia masih berada jauh di bawah publikasi negara-negara maju, bahkan juga berada di bawah Malaysia, Singapura, dan Thailand. Namun, trend ini mengalami peningkatan dimana pada triwulan 2018 Indonesia berhasil menggeser Singapura dan akhirnya mampu menempati urutan ke-2 di ASEAN setelah Malaysia.

$$
\text { Tujuan dikeluarkannya }
$$

Permenristekdikti Nomor 20 Tahun 2017 adalah untuk: 1) mendorong dosen yang sudah berada pada jenjang jabatan akademik Lektor Kepala dan Profesor untuk melaksanakan tugasnya sebagai pendidik profesional dan ilmuwan dengan melaksanakan tridarma perguruan tinggi secara sungguh-sungguh, 2) mendorong Lektor Kepala dan Profesor untuk secara aktif dan produktif melakukan publikasi ilmiah di jurnal nasional terakreditasi, jurnal internasional, dan jurnal internasional bereputasi, dan 3) meningkatkan jumlah publikasi dosen dan ilmuwan Indonesia pada tingkat internasional sehingga mampu bersaing dengan publikasi bangsa-bangsa lain seja dengan Nawacita serta untuk mempero No rekognisi internasional terhadap publikasii ilmiah ilmuwan Indonesia.

Selanjutnya, dengan dikeluarkannyag

Permenristekdikti Nomor 20 Tahun 2017 maka hasil yang diharapkan adalah: 1) meningkatnya jumlah publikasi dosen pada jurnal nasional terakreditasi, jurnal internasional, dan jurnal internasional bereputasi, 2) meningkatnya kuantitas dan kualitas jurnal nasional terakreditasi, dan jurnal-jurnal Indonesia yang masuk kategori jurnal internasional terindeks dan bereputasi, dan 3) meningkatnya peringkat daya saing Indonesia pada publikasi ilmiah di tingkat internasional.

Sejalan dengan dikeluarkannya Permenristekdikti Nomor 20 Tahun 2017 tentang Tunjangan Profesi Dosen dan Tunjangan Kehormatan Guru Besar, Universitas Padjadjaran merupakan salah satu institusi yang mendorong para Dosen dan Guru Besar untuk meningkatkan produktivitas jumlah publikasinya baik Nasional Berakreditasi maupun Internasional bereputasi. Dalam portal Scopus tahun 2017 Universitas Padjadjaran termasuk kedalam sepuluh besar perguruan tinggi yang minat publikasinya banyak. Oleh sebab itu, untuk mendorong dan meningkatkan produktitivitas minat publikasi dalam hal ini menulis artikel di jurnal ilmiah perlu adanya upaya untuk kearah kesana, dengan munculnya beberapa jurnal ilmiah di Universitas Padjadjaran yang mana merupakan bentuk wadah penulisan artikel ilmiah, menjadi bukti bahwa Universitas Padjadjaran menginginkan dosen baik asisten ahli, lektor, lektor kepala dan guru besar menjadi salah satu rujukan tolak ukur bagi institusi yang lain.

Namun seiring berjalannya waktu, perkembangan minat menulis para dosen khususnya di Universitas Padjadjaran, khususnya di lingkungan Fakultas Ilmu Sosial dan Ilmu Politik dalam 3 tahun terakhir ini, baik dosen yang memiliki jabatan akademik sebagai Asisten Ahli, Lektor, Lektor Kepala, maupun Guru Besar, tercatat adanya peningkatan prestasi dalam publikasi ilmiah internasional seperti yang dapat dilihat pada tabel 2 di bawah ini:

Tabel 2. Jumlah Artikel Berdasarkan
Komposisi Jabatan Fungsional
Dosen FISIP Unpad Tahun 2015-2018 Jumlah Artikel (2015-2017) \begin{tabular}{|l|c|c|} 
Jabatan Fungsional & Scopus & Google Scholar
\end{tabular}

\begin{tabular}{|l|c|c|}
\hline Guru Besar & 3 & 65 \\
\hline Lektor Kepala & 3 & 224 \\
\hline Lektor & 2 & 279 \\
\hline Asisten Ahli $\quad$ Total & 4 & 147 \\
\hline \multicolumn{1}{|c|}{} & $\mathbf{1 2}$ & $\mathbf{7 1 5}$ \\
\hline
\end{tabular}

Sumber: Hasil Pengolahan Data Per Januari 2018 
Fakultas Ilmu Sosial dan Ilmu Politik Universitas Padjadjaran adalah salah satu fakultas yang mempunyai jumlah Jurnal yang ber-ISSN terbanyak bila dibandingkan dengan fakultas-fakultas lainnya di lingkungan Universitas. FISIP Unpad memiliki 11 jurnal ber-ISSN, diantaranya yaitu: Adbispreneur, Umbara, Sosioglobal, Cosmogov, Jurnal Wacana Politik, Intermestic, Share: Social Work Journal, Prosiding Penelitian dan Pengabdian kepada Masyarakat, JANE, Manajemen Pelayanan Publik, dan Focus: Praktik Pekerjaan Sosial yang sedang menunggu nomor ISSN dari PDII LIPI. Begitu pun dengan jumlah dosen yang ada di Fakultas Ilmu Sosial dan Ilmu Politik Universitas Padjadjaran berjumlah 173 orang dengan komposisi Jabatan Fungsional berjumlah 10 orang Guru Besar, 44 orang Lektor Kepala, 79 orang Lektor, serta 39 orang Asisten Ahli.

Dengan melihat kondisi seperti itu, Dalam penelitian ini akan mendeskripsikan dan menganalisis diantaranya:

1. Bagaimana produktivitas penulisan artikel jurnal ilmiah di kalangan dosen Fakultas Ilmu Sosial dan Ilmu Politik Universitas Padjadjaran;

2. Bagaimana komposisi jabatan fungsional dosen terkait produktivitas penulisan artikel ilmiah;

3. Hambatan dalam produktivitas dosen dalam penulisan artikel ilmiah

\section{A. Tinjauan Pustaka}

Yuniarsih dan Suwatno (2009), produktivitas kerja menunjukkan tingkat kemampuan pegawai dalam mencapai hasil output, terutama dilihat dari sisi kuantitasnya. Selain itu, dapat diartikan sebagai hasil konkrit (produk) yang terbentuk oleh individu atau kelompok, selama satuan waktu tertentu dalam suatu proses kerja.

Dewan Produktivitas Nasional (DPN) dalam Tjiptoheriyanto dan Nagib (2008), telah merumuskan 2 (dua) pengertian tentang produktivitas. Pertama, pengertian yang relatif abstrak dan menyangkut sistem nilai, dimana produktivitas adalah sikap mental yang melihat hari esok adalah lebih baik dari hari ini. Kedua, pengertian yang lebih bersifat teknis, yaitu rasio dari keluaran yang dikehendaki dengan semua masukan yang dipakai dalam menghasilkan keluaran. Rumusan kedua untuk menekankan bahwa untuk pencapaian produktivitas tidaklah sama dengan pencapaian produksi. Jika aspek produktivitas ingin diperhatikan dalam peningkatan produksi, maka penggunaan masukan selain berkaitan dengan pertanyaan how much juga berkaitan dengan pertanyaan how well. Jadi dalam pengertian ini keluaran yang terbentuk selain memenuhi kriteria dalam kuantitas, juga memenuhi kriteria mutu.

Mangkuprawira dan Hubeis (2007), produktivitas adalah rasio output dan input suatu proses produksi dalam periode tertentu. Input terdiri atas manajemen, pegawai, biaya produksi, peralatan dan waktu. Output meliputi produksi, produk penjualan, pendapatan, pangsa pasar dan kerusakan produk.

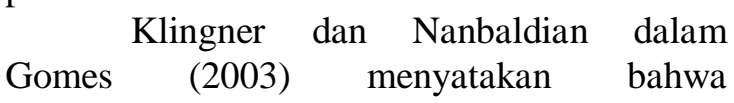
produktivitas merupakan fungsi perkalian dari usaha pegawai (effort), yang didukung dengan motivasi yang tinggi, dengan kemampuan pegawai (ability), yang diperoleh dari latihanlatihan. Produktivitas yang meningkat berarti kinerja yang baik akan menjadi feedback bagi usaha atau motivasi pekerja pada tahap berikutnya. Proses keterkaitan ini dijelaskan oleh Klingner dan Nanbaldian lewat Gambar 1.

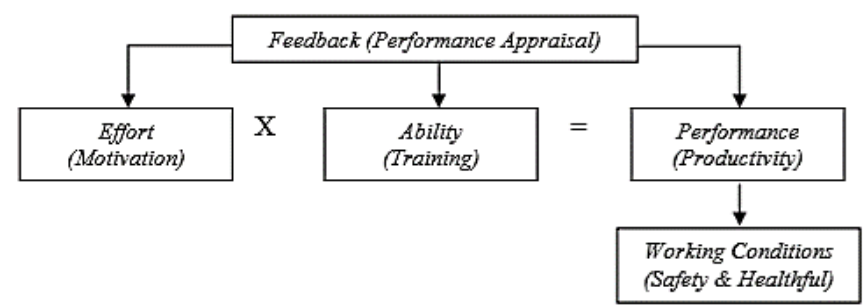

Gambar 1. Kaitan usaha dan kemampuan dengan produktivitas menurut Klingner dan Nanbaldian dalam Gomes (2003)

\section{Faktor-faktor Produktivitas}

Dalam produktivitas terdapat minimal 2 (dua) aspek yang penting untuk dipertimbangkan dalam menganalisis tingkat produktivitas pegawai, yaitu internal dan eksternal. Faktor internal pegawai merupakan faktor yang berasal dari diri pegawai dan dapat terjadi karena unsur alami (bakat) dan bukan alami (belajar dan berlatih). Sedangkan faktor eksternal adalah faktor yang berasal dari luar kemampuan pegawai, namun sangat menentukan seberapa berhasilnya suatu pekerjaan. Contohnya penggunaan teknologi dan manajemen profesional (Tjiptoheriyanto 
dan Nagib, 2008). Yuniarsih dan Suwatno (2009), faktor-faktor yang memengaruhi produktivitas dapat dikelompokkan menjadi 2 (dua), yaitu faktor internal dan faktor eksternal. Keterkaitan antar faktor manusia dan lingkungan internal organisasi terhadap produktivitas dapat dilihat pada Gambar 2.

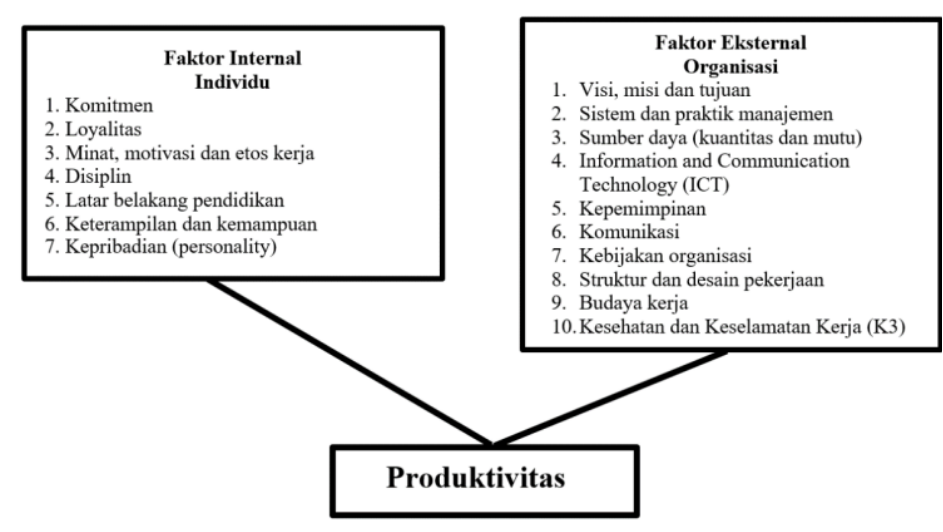

Gambar 2. Faktor-faktor yang memengaruhi produktivitas menurut Yuniarsih dan Suwatno (2009)

\section{METODE}

Peneliti akan menggunakan metode penelitian kualitatif deskriptif dengan instrumen penelitian berupa kuisioner, wawancara, observasi, dan dokumentasi. Menurut Nazir (1998: 63). Populasi sasaran dalam riset ini adalah pihak-pihak yang berkaitan erat dengan subjek penelitian, yaitu dosen di Fakultas Ilmu Sosial dan Ilmu Politik Universitas Padjadjaran.

Pengambilan sampel dalam riset ini dilakukan dengan hasil dari sitasi dan indeksasi (SINTA) yakni dengan melihat SINTA Score.

Lokasi riset dilaksanakan di Fakultas Ilmu Sosial dan Ilmu Politik Universitas Padjadjaran, yang beralamat di Kampus Jatinangor Jl. Raya Bandung- Sumedang Km. 21. Jatinangor Kabupaten Sumedang 45363.

Waktu pelaksanaan riset adalah selama 1 (satu) tahun untuk mengamati, mengobservasi, dan menganalisa produktivitas penulisan artikel ilmiah di kalangan dosen di lingkungan kampus FISIP Unpad.

\section{PEMBAHASAN}

Kewajiban publikasi yang sudah diatur bagi dosen dan peneliti diharapkan dapat mendorong peningkatan jumlah dan mutu publikasi ilmiah pada tingkat nasional dan internasional sehingga Indonesia mampu bersaing dengan bangsa-bangsa lain.

Untuk memudahkan pendataan dan pemetaan publikasi ilmiah yang dilakukan oleh akademisi dan peneliti di Indonesia maka Direktur Jenderal Penguatan Riset dan Pengembangan Kemenristekdikti menginisiasi terbangunnya Sistem Indeksasi dan Sitasi Indonesia (SINTA). SINTA merupakan pusat indeks, sitasi, dan kepakaran terbesar di Indonesia berbasis dalam jaringan yang menawarkan akses cepat, mudah, dan komprehensif untuk mengukur unjuk kerja peneliti dan institusi berdasarkan publikasi yang dihasilkan serta kinerja jurnal berdasarkan jumlah artikel dan sitasi yang dihasilkan. SINTA menyediakan benchmark and analysis, identifikasi kekuatan riset setiap institusi, memperlihatkan kolaborasi penelitian, menganalisis tren penelitian, dan direktori pakar. Konten SINTA berasal dari publikasi akademisi dan peneliti di Indonesia serta jurnal Indonesia yang sudah terbit secara elektronik yang memiliki profil publikasi dan sitasi di pengindeks bereputasi. Sistem SINTA dikembangkan untuk mengintegrasikan publikasi dan jurnal yang terbit di Indonesia sehingga dapat dipetakan kinerja penulis, jurnal dan institusi berdasarkan jumlah publikasi dan sitasi yang diperoleh serta peta kepakaran. SINTA versi 1.0 pada tahun 2017 akan menampilkan (1) peringkat dan profil jurnal, (2) peringkat dan profil institusi, (3) peringkat dan profil penulis, dan (4) penelusuran.

Dalam riset ini, peneliti mencoba untuk memetakan publikasi ilmiah dosen FISIP Unpad dengan berdasarkan pada hasil sementara jumlah publikasi yang telah terindeks SINTA bagi para dosen di lingkungan Fakultas Ilmu Sosial dan Ilmu Politik Universitas Padjadjaran, dilihat berdasarkan portal SINTA (Sistem Indeksasi dan Sitasi Indonesia) meskipun dalam prosesnya masih manual oleh tim portal SINTA. 
Tabel 3.

Persentase Dosen terdaftar di GS \& Scopus

Tanggal Cek 2 Agustus 2018

\begin{tabular}{|c|c|c|c|c|c|c|c|c|c|c|c|}
\hline \multirow[b]{2}{*}{ No } & \multirow[b]{2}{*}{$\begin{array}{l}\text { Program } \\
\text { Studi }\end{array}$} & \multirow[b]{2}{*}{$\begin{array}{c}\text { Jumlah } \\
\text { Dosen }\end{array}$} & \multicolumn{4}{|c|}{ Scopus } & \multicolumn{4}{|c|}{ Google Scholar } & \multirow[b]{2}{*}{$\begin{array}{l}\text { SINTA } \\
\text { Score }\end{array}$} \\
\hline & & & $\frac{\mathscr{e}}{\stackrel{0}{e}}$ & 兽 & 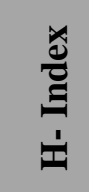 & 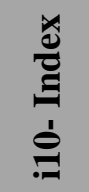 & 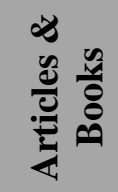 & D气 & 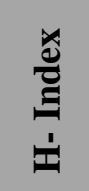 & 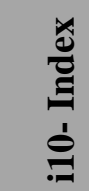 & \\
\hline 1 & $\begin{array}{l}\text { Administrasi } \\
\text { Bisnis }\end{array}$ & 26 & 0,58 & 0,04 & 0,04 & - & 12,81 & 17,12 & 1,27 & 0,27 & 0,24 \\
\hline 2 & $\begin{array}{l}\text { Administrasi } \\
\text { Publik }\end{array}$ & 29 & 0,59 & 0,59 & 0,10 & - & 13,10 & 12,86 & 1,00 & 0,34 & 0,25 \\
\hline 3 & Antropologi & 20 & 2,15 & 11,35 & 0,85 & 0,40 & 11,35 & 52,15 & 2,20 & 1,25 & 1,59 \\
\hline 4 & $\begin{array}{l}\text { Hubungan } \\
\text { Internasional }\end{array}$ & 32 & 0,34 & 0,03 & 0,03 & - & 8,91 & 14,16 & 0,69 & 0,13 & 0,21 \\
\hline 5 & $\begin{array}{l}\text { Ilmu } \\
\text { Pemerintahan }\end{array}$ & 21 & 0,10 & 0,14 & 0,10 & - & 11,48 & 7,62 & 1,19 & 0,05 & 0,08 \\
\hline 6 & Ilmu Politik & 12 & 0,67 & - & - & - & 13,08 & 29,17 & 0,92 & 0,33 & 0,37 \\
\hline 7 & $\begin{array}{l}\text { Kesejahteraan } \\
\text { Sosial }\end{array}$ & 26 & 0,15 & - & - & - & 25,46 & 23,58 & 1,50 & 0,81 & 0,16 \\
\hline 8 & Sosiologi & 7 & - & - & - & - & 18,00 & 12,29 & 1,14 & 0,14 & 0,11 \\
\hline & & 173 & & & & & & & & & \\
\hline
\end{tabular}

Sumber: data diolah, 2018

Tabel 4. SINTA Score

\begin{tabular}{|c|l|c|c|}
\hline No & \multicolumn{1}{|c|}{ Nama } & SINTA Score & Jabatan Fungsional \\
\hline 1 & M. Benny Alexandri & 1,52 & Lektor Kepala \\
\hline 2 & Ida Widianingsih & 1,95 & Lektor Kepala \\
\hline 3 & Mas Dadang Enjat Munajat & 2,53 & Asisten Ahli \\
\hline 4 & Oekan Soekotjo Abdoellah & 14,53 & Guru Besar \\
\hline 5 & Budhi Gunawan & 8,48 & Lektor Kepala \\
\hline 6 & Budiawati Supangkat & 4,8 & Lektor \\
\hline 7 & Rini S. Soemarwoto & 1,13 & Lektor \\
\hline 8 & Junardi Harahap & 1,45 & Lektor \\
\hline 9 & Yanyan Mochamad Yani & 4,04 & Guru Besar \\
\hline 10 & Obsatar Sinaga & 1,35 & Guru Besar \\
\hline 11 & Caroline Paskarina & 2,74 & Lektor \\
\hline 12 & Yusa Djuyandi & 1,57 & Asisten Ahli \\
\hline 13 & Santoso Tri Raharjo & 1,37 & Lektor Kepala \\
\hline 14 & Maulana Irfan & 1,02 & Asisten Ahli \\
\hline
\end{tabular}


Berdasarkan hasil sementara pada tabel 4 data dari Portal SINTA sampai dengan tertanggal 2 Agustus 2018, diperoleh data bagi Dosen FISIP Unpad pada SINTA Score tertinggi di bawah angka yang diperoleh range antara SINTA Score 1,02 sampai dengan 14,53 diantaranya.

\section{Komposisi Jabatan Fungsional}

Fakultas Ilmu Sosial dan Ilmu Politik Universitas Padjadjaran, kini memiliki 170 dosen yang masih aktif, dengan komposisi jabatan fungsional akademik Asisten Ahli, Lektor, Lektor Kepala dan Guru Besar. Setelah data diolah berdasarkan SINTA Score sementara, maka diperoleh Jabatan Fungsional yang produktif terkait penulisan artikel jurnal ilmiah, yakni:

1. Guru Besar:

a. Oekan Soekotjo Abdoellah (score: 14,53)

b. Yanyan Mochamad Yani (score: 4,04)

c. Obsatar Sinaga (score: 1,35)

2. Lektor Kepala:

a. Budhi Gunawan (score: 8,48 )

b. Ida Widianingsih (score: 1,95 )

c. M. Benny Alexandri (score: 1,52)

3. Lektor
a. Budiawati Supangkat (score: 4,8)
b. Caroline Paskarina (score: 2,74 )
c. Junardi Harahap (score: 1,45)

4. Asisten Ahli

a. Mas Dadang Enjat Munajat (score: 2,53)

b. Yusa Djuyandi (score: 1,57)

c. Maulana Irfan (score: 1,02)

Setelah diketahui nama-nama tersebut, peneliti selanjutnya akan melakukan wawancara lebih dalam untuk mengetahui bagaimana produktivitas penulisan artikel jurnal ilmiah beserta hambatan apa saja yang dialami dalam penulisan artikel jurnal ilmiah.

\section{Luaran yang dicapai}

Analisis Karakteristik Responden Dosen FISIP Universitas Padjadjaran yakni:

1. Berdasarkan Jenis Kelamin diperoleh Laki-laki berjumlah 22 orang (53\%), sedangkan Perempuan berjumlah 19 orang (47\%).

2. Berdasarkan Jabatan Fungsional diperoleh Asisten Ahli (AA) sebesar
4 orang (11\%), Lektor (L) sebesar 10 orang (24\%), Lektor Kepala (LK) sebesar 27 orang (65\%).

3. Berdasarkan Jenjang Pendidikan diperoleh S2 sebesar 12 orang (29\%), dan S3 sebesar 29 orang (71\%).

4. Berdasarkan Lama Bekerja diperoleh:

$\begin{array}{cccc}\text { No } & \begin{array}{c}\text { Lama } \\ \text { Kerja }\end{array} & \text { Hasil } & \text { \% } \\ 1 & 0-5 & 8 & 18 \\ 2 & 06-10 & 2 & 6 \\ 3 & 11-15 & 16 & 39 \\ 4 & 16-20 & 7 & 17 \\ 5 & 21-25 & 4 & 8 \\ 6 & 26-30 & 2 & 6 \\ 7 & 31-35 & 2 & 6\end{array}$

Berdasarkan hasil kuesioner yang diberikan kepada sejumlah 41 orang dosen saat mengikuti monitoring evaluasi Hibah Internal Unpad di Fakultas Ilmu Sosial Ilmu Politik Universitas Padjajaran, maka ada 2 faktor yang mendorong produktivitas seseorang, diantaranya faktor internal dalam dirinya dan faktor eksternal diluar dirinya yaitu organisasi.

Hasil penelitian menunjukan bahwa faktor internal yang mempengaruhi Produktivitas Penulisan Artikel Jurnal Ilmiah di Kalangan Dosen FISIP Unpad, adalah item pernyataan nomor 3 yaitu: Profesi yang saya miliki, dituntut untuk selalu membuat/menulis karya tulis ilmiah dengan nilai 191 dari nilai rata-rata 171,6. Selanjutnya untuk faktor eksternal yang mempengaruhi Produktivitas Penulisan Artikel Jurnal Ilmiah di Kalangan Dosen FISIP Unpad, adalah item pernyataan nomor 7 yaitu: Fakultas dan Universitas, memberikan insentif jika karya tulis ilmiah dapat publish di jurnal setiap 6 (enam) bulan 1 kali (semester).

Adapun yang tidak mempengaruhi pada faktor internal adalah pada item nomor 9 yaitu: pernyataan Waktu yang saya miliki cukup luang untuk menulis karya tulis ilmiah dan item nomor 6 yaitu: Saya merasa kurang memiliki dana untuk mempublikasikan karya tulis ilmiah serta item nomor 10 yaitu: 
Menulis karya tulis ilmiah menjadi kewajiban saya untuk dapat menerbitkannya di jurnal setiap 6 (enam) bulan 1 kali (semester).

\section{Hambatan Dalam Produktivitas Penulisan Artikel Ilmiah}

Berdasarkan hasil kuesioner mengenai hambatan dalam produkdtivitas penulisan artikel ilmiah, diperoleh berdasarkan faktor internal dan faktor eksternal yaitu:

Faktor Internal

1. Waktu yang saya miliki cukup luang untuk menulis karya tulis ilmiah.

2. Saya merasa kurang memiliki dana untuk mempublikasikan karya tulis ilmiah.

3. Menulis karya tulis ilmiah menjadi kewajiban saya untuk dapat menerbitkannya di jurnal setiap 6 (enam) bulan 1 kali (semester).

\section{Faktor Eksternal}

1. Fakultas dan Universitas, memberikan sangsi jika tidak mempublikasikan karya tulis ilmiah di jurnal setiap 6 (enam) bulan 1 kali (semester).

2. Fakultas dan Universitas, mengurangi tugas lain sehingga saya memiliki waktu untuk menulis karya tulis ilmiah.

3. Fakultas dan Universitas, meningkatkan akses informasi dan layanan untuk jurnal internasional.

4. Fakultas dan Universitas, menjalin kerja sama dengan beberapa pihak terkait untuk mempermudah penerbitan jurnal.

\section{SIMPULAN}

Berdasarkan hasil penelitian menunjukan bahwa faktor internal yang mempengaruhi Produktivitas Penulisan Artikel Jurnal Ilmiah di Kalangan Dosen FISIP Unpad, pada pernyataan: Profesi yang saya miliki, dituntut untuk selalu membuat/menulis karya tulis ilmiah dengan skor 191. Sedangkan pada faktor eksternal yang mempengaruhi Produktivitas Penulisan Artikel Jurnal Ilmiah di Kalangan Dosen FISIP Unpad, pada pernyataan: Fakultas dan Universitas, memberikan insentif jika karya tulis ilmiah dapat publish di jurnal setiap 6 (enam) bulan 1 kali (semester) dengan skor 167.

Untuk Jabatan fungsional akademik, dapat disimpulkan berdasarkan SINTA yakni,
1. Guru Besar: Oekan Soekotjo Abdoellah (score: 14,53)

2. Lektor Kepala: Budhi Gunawan (score: $8,48)$

3. Lektor: Budiawati Supangkat (score:

4,8)

4. Asisten Ahli: Mas Dadang Enjat

Munajat (score: 2,53)

Adapun hambatan yang dikemukakan, yaitu: faktor internal yakni waktu yang saya miliki cukup luang untuk menulis karya tulis ilmiah; saya merasa kurang memiliki dana untuk mempublikasikan karya tulis ilmiah; dan menulis karya tulis ilmiah menjadi kewajiban saya untuk dapat menerbitkannya di jurnal setiap 6 (enam) bulan 1 kali (semester). Sedangkan faktor eksternal yakni: Fakultas dan Universitas, memberikan sangsi jika tidak mempublikasikan karya tulis ilmiah di jurnal setiap 6 (enam) bulan 1 kali (semester); Fakultas dan Universitas, mengurangi tugas lain sehingga saya memiliki waktu untuk menulis karya tulis ilmiah; dan Fakultas dan Universitas, meningkatkan akses informasi dan layanan untuk jurnal internasional; dan Fakultas dan Universitas, menjalin kerja sama dengan beberapa pihak terkait untuk mempermudah penerbitan jurnal.

\section{SARAN}

Berdasarkan kesimpulan diperoleh bahwa, produktivitas penulisan artikel ilmiah pada faktor internal dan eksternal yakni:

1. Waktu yang dimiliki terasa kurang, karena adanya beban tugas tambahan dalam organisasi.

2. Dana untuk mempublikasikan masih kurang, oleh karena itu baik Universitas dan Fakultas memberikan hibah-hibah lebih banyak lagi.

3. Tidak adanya kewajiban publikasi dalam satu semester, sehingga tidak memberatkan dosen.

4. Pihak Fakultas, harus lebih memfasilitasi kembali terkait submission naskah, penulisan artikel jurnal internasional, dan sebagainya.

5. Pihak Fakultas atau Universitas, harus lebih memfasilitasi kembali kerjasama dengan pengelola jurnal yang jurnalnya terindeks Internasional. 


\section{UCAPAN TERIMA KASIH}

Penulis ingin menyampaikan rasa terima kasih kepada Universitas Padjadjaran yakni Hibah Internal Unpad skema Riset Tenaga Kependidikan Universitas Padjadjaran, yang telah memberikan kesempatan. Dan tak lupa penulis juga menyampaikan rasa hormat dan terima kasih kepada Dr. Caroline Paskarina, S.IP., M.Si selaku pembimbing dalam menyelesaikan proses laporan RTKU. Dan orang-orang yang berperan serta mendukung dalam menyelesaikan laporan RTKU, kami haturkan terima kasih.

\section{DAFTAR PUSTAKA}

\section{Buku}

Gomes, F. C. (2003). Manajemen Sumber Daya Manusia (Terjemahan). Yogyakarta: Andi

Mangkuprawira, Tb. S. dan A. V. Hubeis. (2007). Manajemen Mutu Sumber Daya Manusia. Ghalia Indonesia, Jakarta.

Mawardi, Dodi. (2009). Cara Mudah Menulis Buku, dengan Metode 12 Pas. Jakarta: Raih Asa Sukses.

Nazir, Mohammad. (1998). Metode Penelitian. Jakarta: Ghalia Indonesia.

Lukman; dkk. (2017). Pedoman Publikasi Ilmiah, Jakarta: Direktorat Pengelolaan Kekayaan Intelektual; Direktorat Jenderal Penguatan Riset dan Pengembangan Kementerian Riset, teknologi, dan Pendidikan Tinggi.

Tjiptoheriyanto, P. dan Nagib, L. (2008). Pengembangan SDM : diantara Peluang dan Tantangan. Jakarta: LIPI Press.

Yuniarsih, T. dan Suwatno. (2009). Manajemen Sumber Daya Manusia Teori, Aplikasi dan Isu Penelitian. Bandung: Alfabeta.

\section{Jurnal}

Irianti, P. (2017). Produktivitas Penulis Artikel Majalah Ilmiah Psikologi Universitas Gadjah Mada Menggunakan Dalil Lotka. Berkala Ilmu Perpustakaan dan Informasi, 13(2), 205-216.

Nelisa, M. (2012). Produktivitas pengarang artikel bidang ilmu perpustakaan dan informasi di Indonesia tahun 1978-
2007: Analisis bibliometrika menggunakan hukum Lotka. BACA: Jurnal Dokumentasi dan Informasi, 30(2), 73-95.

\section{Peraturan-perundangan}

Undang-Undang Nomor 12 Tahun 2012

tentang Pendidikan Tinggi

Undang-undang Nomor 14 tahun 2015 tentang Guru dan Dosen

Peraturan Menteri Penertiban Aparatur Negara dan Reformasi Birokrasi Nomor 17 tahun 2013 tentang Jabatan Fungsional Dosen dan Angka Kreditnya

Peraturan Menteri Pendidikan dan

Kebudayaan (Permendikbud) Nomor 49 tahun 2014 tentang Standar Nasional Pendidikan Tinggi (SN-DIKTI)

Peraturan Menteri Riset, Teknologi dan Pendidikan Tinggi Nomor 20 tahun 2017 tentang Tunjangan Profesi Dosen dan Tunjangan Kehormatan Profesor

Petunjuk Teknis Peraturan Menteri Riset, Teknologi, dan Pendidikan Tinggi Nomor 20 Tahun 2017 Tentang Tunjangan Profesi Dosen dan Tunjangan Kehormatan Profesor, hal. 2-8

Direktorat Pengelolaan Kekayaan Intelektual Direktorat Jenderal Penguatan Riset dan Pengembangan Kementerian Riset, Teknologi, dan Pendidikan Tinggi 2017, berjudul "Pedoman Publikasi Ilmiah", hal. 17-18

\section{Website}

Anwar, Chiftul Mawalia Anwar. (2016). Pola Produktivitas Pengarang dalam Jurnal di Fakultas Ilmu Sosial dan Ilmu Politik Universitas Airlangga Tahun 2009-2012. (http://journal.unair.ac.id/downlo ad-fullpapersjurnal\%20chiftul.pdf diakses tanggal 24 Januari 2018)

(http://www.scimagojr.com/countryrank.php diakses tgl 23 Januari 2018)

(https://doaj.org/search?source diakses tgl 23 Januari 2018)

(http://sinta2.ristekdikti.go.id/journals?q=\&se $\operatorname{arch}=1 \& \operatorname{sinta}=1$ diakses tgl 23

Januari 2018) 
KANDAGA Vol. 1 | Nomor 1 Edisi Mei 2019

E-ISSN : **** _ ****

(http://drpmi.unpad.ac.id/riset diakses

indonesia-jauh-di- bawah-

tanggal 24 Januari 2018)

(http://fisip.unpad.ac.id/jurnal/ diakses

tanggal 24 Januari 2018)

(http://jurnal.unpad.ac.id/search/category/

1172 diakses tanggal 24 Januari 2018)

(http://litbang.kemendagri.go.id/websit

e/jumlah-publikasi-ilmiah-

malaysia/ diakses tgl 22

Agustus 2018 jam. 21.56 wib)

(http://www.kopertis12.or.id/2018/04/13/akhir nya-la mpaui-singapura-publikasi-

ilmiah-indonesia- ke-2-asean.html diakses tgl 22 Agustus 2018 jam. $22.41 \mathrm{wib})$ 